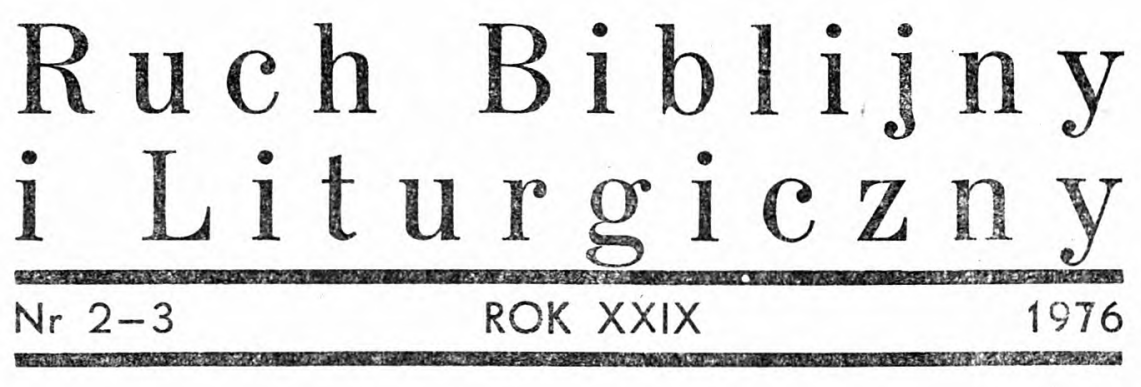

\author{
Ks. Boleslaw Kosecki
}

\title{
WYZNANIE GRZECHÓW W PRAKTYCE POKUTY KOSCIOLA NA ZACHODZIE
}

Zamierzona przez II Sobór Watykański odnowa życia chrześcijańskiego stawia dziś Kościól przed zadaniem nowego przemyślenia i dostosowania do potrzeb i mentalności współczesnego człowieka wiele pojęć i instytucji, które przez wieki całe stanowiły o jego żywotności i formowały jego duchowe oblicze. Za wcześnie jeszcze byłoby mówić o jakimś bilansie tego, co osiągnięto, czy silić się na sformułowanie jakichś prognoz odnośnie tego, co najważniejsze czy najbardziej pożyteczne. Jedno jest pewne, że $\mathrm{w}$ tym powszechnym dziele odnowy liturgia zajęła miejsce przodujące, a jej odnowa nabiera dziś szczególnego znaczenia.

Zgodnie $z$ wytycznymi Soboru, przystosowaniu i odnowie poddane zostały prawie wszystkie sakramenty. Do przemyślenia i nowego opracowania - tak pod względem teologicznego ujęcia i sposobu sprawowania - pozostał jeszcze sakrament pokuty.

Trzeba powiedzieć zaraz na wstępie, że wokół tego sakramentu wytworzył się w niektórych krajach na Zachodzie w ostatnich dziesiąkach lat jakiś niezdrowy klimat uprzedzenia, co ogromnie wpływa na zmniejszenie się frekwencji przystępujących do spowiedzi. Właśnie spowiedź dla wielu wierzących staje się dziś punktem najbardziej newralgicznym i stąd jej praktyka tyle napotyka trudności i oporów. Przyczyn, które złożyły się na powstanie tego niekorzystnego klimatu duchowego, jest na pewno wiele i można by im poświęcić osobny artykuł. Ogólnie rzec biorąc, można zauważyć pewien brak poczucia winy (grzechu) i odpowiedzialności osobistej za swe postępowanie. To przytępienie zmysłu moralnego rodzi $z$ kolei brak zrozumienia dla potrzeby spowiedzi, a nawet, szczególnie u młodych, pewną awer- 
sję do wszystkiego, co ma charakter samooskarżenia się ze swoich przewinień. Nie rzadko też zdarza się, że nawet ci, co często klękają u kratek konfesjonału, spowiadają się albo powierzchownie i niedbale, albo szablonowo, traktując spowiedź jako pewnego rodzaju rutynę.

Wobec takiego stanu rzeczy podnoszą się coraz częściej głosy krytyki przeciw zbyt prawniczemu i reistycznemu pojmowaniu sakramentu pokuty, w którym za mało uwzględnia się potrzebę osobistego zaangażowania. Wielu teologów i pastoralistów, nie rezygnując bynajmniej z postulatu spowiedzi indywidualnej, opowiada się za przywróceniem w Kościele dawnych praktyk pokutnych o charakterze bardziej społecznym i wychowawczym, czyli za dowartościowaniem tych elementów, które spełniały funkcje ekspiacji i naprawy zła, a które z biegiem wieków ustąpiły miejsca aktom bardziej osobistym (żal, skrucha grzesznika, indywidualne wyznanie grzechów kapłanowi, rozgrzeszenie indywidualne kapłana) i zredukowane zostały do aktów pokuty raczej symbolicznej i indywidualnej ${ }^{1}$. Nie brak też głosów za zniesieniem spowiedzi usznej i przejściem do praktyki sprawowania sakramentu pokuty w sposób zbiorowy, polegający na spełnianiu pewnych ustalonych praktyk pokutnych i udzielaniu rozgrzeszenia wspólnego po uprzednim wyznaniu grzechów w formie ogólnej i zbiorowej 2 .

Święta Kongregacja Sakramentów, podobnie jak Kongreg. dla spraw Kultu Bożego i Kongreg. Doktryny Wiary zdając sobie doskonale' sprawę, jak wielką rolę spełniał sakrament pokuty w utrzymaniu poziomu życia chrześcijańskiego w Kościele w ciągu stuleci, nie moga odstąpić od tradycji i doświadczenia wieków i zadowolić się rozwiązaniem zbyt uproszczonym albo mijającym się z celem tego sakramentu. Z drugiej strony, nie mogą ignorować pewnych faktów i pewnych postulatów duszpasterskich słusznych, jako też psychiki dzisiejszego człowieka, innej niż w okresie średniowiecza, a nawet baroku.

Żeby dobrze rozważyć i przeprowadzić dzieło odnowy sakramentu pokuty w sposób nie budzący zastrzeżeń, tj. tak, żeby sakrament ten pozostał nadal tym, czym był dotąd w Kościele, mianowicie sakramentem oczyszczenia, pojednania i powrotu do Boga - środkiem pomocnym i nieodzownym do zbawienia - trzeba nawiązać do historii i tradycji Kościoła. Tylko w tym kontekście, bez uprzedzeń i bez narzucania teoretycznych rozwiązań, móżemy spokojnie przyjrzeć się faktom, tj. sposobom sprawowania tego sakramentu i ich przemianom na przestrzeni wieków oraz dojrzeć i obiektywnie ocenić racje teologiczne lub pastoralne tych przemian.

1 Zob. B. Carra de Vaux Saint-Cyr, La confession en contestation, Paris 1970; F. Fun k e, Rzut oka na literaturę o spowiedzi, Concilium 1-10, 1971, wyd. Pallottinum, s. 54-63.

2 Zob. F. Funk e, art. cyt., s. 60-61; Notitiae, nr 77, 1972, s. 305307: ostrzeżenie papieża Pawła VI przed nierozważnym wprowadzaniem w życie Kościoła tego rodzaju praktyk. 
Taki też cel chce spełnić niniejszy artykuł. Będzie to próba ukazania $\mathrm{w}$ historycznym zarysie, jak przedstawiało się wyznanie grzechów w praktyce pokuty na Zachodzie, tj. w Kościele łacińskim. Czym wlaściwie to wyznanie grzechów było? Z czym było połączone? Jakie zajmowało miejsce $\mathrm{w}$ całokształcie zmieniającej się na przestrzeni wieków dyscypliny pokutnej Kościoła? Jaką spełniałò rolę w dziele wewnętrznej przemiany grzesznika zwanej conversio, wzgl. metanoia?

\section{WYZNANIE GRZECHÓW W STAROŻYTNOSCI CHRZEŚCIJAŃSKIEJ (do VI, w.)}

Historyk lub badacz zainteresowany początkami i rozwojem praktyki sakramentu pokuty na próżno siliłby się na systematyczne i szczegółowe jej odtworzenie w pierwszych dwóch wiekach, czyli w okresie poapostolskim. Powoływanie się na teksty $z$ Dziejów Apostolskich, z listów św. Pawła i Jakuba, albo na naukę Dwunastu Apostołów, tzw. Didache, lub na Pasterza Hermasa i na pisma Klemensa Aleksandryjskiego i Orygenesa, prowadzą raczej na drogę hipotez, gdyż teksty te sa albo okazyjne, albo fragmentaryczne i niejasne. Ich interpretacja nastręcza dziś jeszcze wiele trudności ${ }^{3}$. Brak $w$ tym czasie jakichkolwiek norm, czyli reguł ogólnych, pozwala przypuszczać, że praktyki pokutne były w tym okresie bardzo zróżnicowane, albo ściślej biorąc - in statu fieri, a więc kształtujące się w zależności od obyczajów, od opinii publicznej i klimatu duchowego poszczególnych Kościołów lokalnych. Poza tym prawie wszystkie te pisma ilustrują praktyki pokutne Kościołów Wschodu, tymczasem nas interesują praktyki Kościoła łacińskiego.

Jeśli chodzi o praktyki pokuty sakramentalnej w Kościele na Zachodzie, to pierwsze świadectwa znajdujemy u Tertuliana (zm. po r. 220) i św. Cypriana (zm. 258) - dwóch najwybitniejszych przedstawicieli Kościoła łacińskiego w III wieku. Z ich pism, jako tęż z późniejszych źródeł, dowiadujemy się, że aż do VI w. pokuta jako sakrament ekspiacji, przebaczenia i poprawy grzesznika miała wybitnie publiczny charakter, podyktowany względami pastoralnymi, czyli wychowawczymi. Praktyki tej pokuty obejmowały oczywiście tylko publicznych grzeszników, tj. tych wiernych, którzy po przyjęciu chrztu dopuścili się ciężkich i jawnych grzechów, przewinienia natomiast lekkie i powszednie gładziły liczne wezwania i modlitwy zanoszone do Chrystusa z prośbą o przebaczenie, a którymi przeplatane było życie w dzień powszedni, np. „Od́puść nam nasze winy” w modlitwie Pańskiej. Rozróżnienie między grzechami ciężkimi a grzechami

3 Zob. B. Pos chm an n, La pénitence et l'onction des malades, Paris 1966, s. 12-39; W. G r a n t, Sakramenty święte, Lublin 1966, cz. II, s. $266 \mathrm{n}$; J. R a mos-R e g idor, Pojednanie w Kościele pierwotnym, Concilium $1-10,1971$, s. $17-26$. 
lekkimi w okresie patrystycznym nie było jeszcze skrystalizowane i nie trzeba go utożsamiać z dzisiejszym naszym podziałem na grzechy śmiertelne i grzechy powszednie ${ }^{4}$.

Zdaniem Tertuliana, chrześcijanin, odkąd wyrzekł się szatana i przyjąl chrzest, już nie powinien więcej grzeszyć. Niemniej ten, który ciężko zgrzeszył i tym samym odpadł (albo wyłączył się) od społeczności Kościoła, nawet po chrzcie ma możliwość naprawienia swego grzechu i uzyskania przebaczenia, a tym samym ma możliwość powrotu do jedności z braćmi i do uczestniczenia w Eucharystii.

Ażeby uzyskać takie przebaczenie, grzesznik musiał odbyć okres surowej pokuty, czyli próby, którą Tertulian nazywa operosa probatio ${ }^{5}$. Zadaniem tej pokuty, na którą składało się wiele praktyk czasem bardzo upokarzających, było wykazanie się przed całą społecznościa Kościoła lokalnego, że penitent nie tylko żałuje szczerze za swoje grzechy i że się do nich publicznie przyznaje, ale że - w poczuciu zniewagi wyrządzonej Bogu i Kościołowi - przyjmuje właśnie te praktyki zlecone mu przez Kościół jako środki naprawienia zła, słowem - daje dostateczną gwarancję, że się rzèczywiście zmienił i zasługuje na przebaczenie. Stąd też, oprócz usposobienia wewnętrznego (, ut non sola conscientia proferatur"), wymagan ood niego aktu zewnętrznego i pubicznego. Tertulian używa na określenie tego aktu wyrazu greckiego exomologêsis powszechnie zapewne używanego w Afryce, albo też równnoznacznego mu wyrazu lacińskiego confessio, lub wreszcie wyrażenia publicatio sui (De paenit. X, 1-10).

$Z$ dalszego tekstu Tertuliana wynika, że tego rodzaju pokuta, czyli wyznanie grzechu i jej przebieg, jako też i samo rozgrzeszenie, wymagały interwencji Kościoła w osobie swoich kapłanów, a szczególnie biskupa. Za autorem Pasterza Hermasem, Tertulian podkreśla bardzo silnie, że grzesznik może otrzymać takie rozgrzeszenie po chrzcie raz tylko w życiu jako drugą wielką łaskę $i$ to jeszcze po wypełnieniu uciążliwej pokuty nałożonej mu przez Kościól. Z tej też racji nazywa ją ,paenitentia secunda et una" w znaczeniu "ultima" i przyrównuje ją do drugiego chrztu, lecz chrztu mozolnego ${ }^{6}$.

Tak pojęta praktyka pokuty, na której Tertulian wycisnąl swoje piętno, przetrwa w Kościele łacińskim aż do wprowadzenia w VII w. nowej praktyki, tzw. ,pokuty taryfowej" częstej i sekretnej. Ten przesadny rygoryzm i niepowtarzalność starożytnej praktyki pokuty stanie się też powodem jej niepopularności i niepowodzenia.

Podobny jak u Tertuliana przebieg praktyk pokuty sakramentalnej znaleźć możemy też w III w. u św. Cypriana, który w 50 lat

4 Zob. W. Granat, dz. cyt., s. 199, 270 n, 295 n; P.-M. Gy, Histoire liturgique du sacrement de pénitence, LMD $\mathrm{nr} 56,1958$, s. 5-21; P. R a d o, Enchiridion liturgicum, Roma 1961, t. II, s. $750 \mathrm{n}$.

5 De paenitentia, IX; PL 1, 1243 B.

${ }_{6}$ Zob. C. Vogel, Péché et pénitence, w dz. zbior. Pastorale du péché, Paris 1961, s. 167 n; B. P o s c h m a n n, dz. cyt., s. 47-51. 
później musiał niejednokrotnie zabierać głos $\mathrm{w}$ polemice $\mathrm{z}$ nowacjanami 7. Cyprian wymaga od grzeszników winnych ciężkich przewinień (apostazji) szczerego nawrócenia się przez pokutę zadośćuczynną i pojednania się z Kościołem, gdyż inaczej nie ma dla nich zbawienia. Pojednanie grzesznika z Kościołem zależy od decyzji biskupa, który ma obowiązek rozpatrzenia sprawy każdego penitenta i nie powinien rozgrzeszać zbyt pochopnie, bez rozeznania ciężkości przewinienia. Kościól więc interweniuje przez swoich ministrów, którzy wyznaczają penitentowi okres pokuty i jej formę oraz czuwają nad jej wykonaniem. Bez tej interwencji nie ma pojednania i przebaczenia ${ }^{8}$.

To stwierdzenie jest dla nas bardzo ważne. Aczkolwiek nie ma tu jeszcze mowy o szczegółowym i indywidualnym wyznaniu grzechów przed biskupem wzgl. innym ministrem, jest jednak wyraźne polecenie, że minister Kościoła, zanim uzna penitenta godym przebaczenia, musi mieć rozeznanie, czyli dowiedzieć się od penitenta o ciężkości jego winy oraz o okolicznościach jej towarzyszących i o jego szczerości nawrócenia, tj. postawie wewnętrznej. Cały przebieg praktyk pokutnych, również bardzo upokarzających, nosi podobnie jak u Tertuliana nazwę confessio albo exomologesis i ma prawie to samo znaczenie, chociaż interpretacja tego ostatniego wyrazu sprawia teologom wielkie trudności. Warto tu podkreślić, że pokuta, która penitent musi wypełnić, poprzedzała moment pojednania i rozgrzeszenia.

$\mathrm{Na}$ ogól, nic nie wskazuje na to, twierdzi Cyryl Vogel ${ }^{9}$, że w pismach Tertuliana i Cypriana wyraz exomologesis albo confessio ma znaczenie publicznego i szczegółowego wyznania grzechów przy obrzędzie pojednania, którego na zakończenie praktyk pokutnych udzielał biskup. Według nowszych opinii, przez wyraz exomologesis należy rozumieć nie jakiś pojedyńczy i jednorazowy akt ograniczający się do publicznego wyznania swoich grzechów przed braćmi w formie szczegółowej wypowiedzi, lecz raczej cały zespól aktów pokutnych wykonanych przez penitenta i mających same przez się charakter samooskarżenia się i przebłagania, czyli upokorzenia się przed Bogiem i przed braćmi w postawie grzesznika wyznającego w ten sposób swoja nędzę moralną i zdającego się całkowicie na milosierdzie Boga i na pomoc Kościoła 10. Jest rzeczą prawdopodobną, twierdzi C. Vogel, że w miarę powiększania się gmin chrześcijańskich, penitênt, pragnący uzyskać publiczne przebaczenie swoich win, wyjawial uprzednio kompetentnemu ministrowi Kościoła, tj. biskupowi, jako przewodni-

7 Zob. B. Poschmann, dz. cyt., s. 58 n; W. Granat, dz. cyt., s. $290 \mathrm{n}$.

${ }_{3}$ Epist. 15, 1; 16, 2; 18, 1; zob. W. Granat, dz. cyt., s. 291, 294.

Z Zob. C. Voge 1 , dz. cyt., s. 175.

10 Zob. C. Vogel, dz. cyt., s. 176; por. B. Poschmann, dz. cyt., s. 52, 99; W. Granat, dz. cyt., s. 290 n; E. V a c andard, Confession, DThC III, $854 \mathrm{n}$. 
kowi lokalnej gminy, indywidualnie i w sekrecie powód, dla którego uważał się winnym pokuty, a więc rodzaj grzechu i jego okoliczności i okazywał gotowość przyjęcia nałożonej mu ekspiacji. Wypadki takiego sekretnego i indywidualnego wyznania grzechów (oczywiście, ciężkich i godzących w reputację całej gminy) miały rzeczywiście miejsce. Świadczy o tym list św. Cypriana, w którym pozwala, by penitent $\mathrm{w}$ obliczu śmierci i $\mathrm{w}$ razie nieobecności prezbytera, odbył swoją exomologezę przed diakonem ${ }^{11}$.

2. WIEK IV, V I VI, CZYLI STADIUII TZW. „POKUTY KANONICZNEJ”

Zdawać by się mogło, że po okresie ciężkich prób dla Kościoła, które miały miejsce w pierwszych trzech wiekach, masowe nawrócenia i przejście w IV w. na łono Kościoła całych prowincji i nowych ludów zachodniej Europy przyniosły z sobą złagodzenie surowych praktyk pokutnych wieków poprzednich i wprowadziły ułatwienia w uzyskaniu rozgrzeszenia. Otóż stało się przeciwnie. Przeczuwając niebezpieczeństwo rozprzężenia dyscypliny w Kościele i zdając sobie sprawę, że mają do czynienia z ludami, których obyczaje trzéba uformować według ducha Ewangelii, biskupi stanęli energicznie w obronie właśnie praktyk pokutnych i obwarowali je szeregiem kanonów, zatwierdzonych następnie na licznych synodach, jakie miały miejsce w tym okresie w Afryce, Hiszpanii i Galii. Tak więc proces ewolucji sakramentu pokuty poszedł w kierunku wyraźnie rygorystycznym. Ujęte $\mathrm{w}$ drobiazgowe niekiedy i kanonami obwarowane przepisy, praktyki pokutne otrzymały w tym okresie liturgiczną oprawę ceremonii, które obok uroczystego charakteru dodały im jeszcze więcej powagi i surowości.

Wielu autorów, między innymi B. Poschman i C. Vogel, szczegółowo przedstawili w swoich monografiach przebieg takiej kanonicznej pokuty i jej rozmaite warianty ${ }^{13}$. Nas interesuje przede wszystkim zagadnienie, jak w tym kontekście przedistawia się problem wyznania grzechów, tzn. czy rzeczywiście znaleźć możemy świadectwa potwierdzające, że oprócz oficjalnej i kanonicznej pokuty publicznej biskupi i prezbiterzy przyjmowali od penitentów wyznanie grzechów indywidualne i sekretne.

U św. Hieronima znajdujemy opinię, że kapłani nie powinni według własnego widzimisię związywać lub rozwiązywać, lecz dopiero po usłyszeniu różnorakich grzechów wyrobić sobie sąd komu maja grzechy odpuścić a komu zatrzymać ${ }^{13}$.

11 Epist. 18, 1; zob. Ks. W. Gran a t, dz. cyt., s. 293.

1. Zob. W. S ch enk, Liturgia sakramentów świętych, Lublin 1964, cz. II, s. 15 . 25; B. P o s c h m a n n, dz. cyt., s. 75-107; C. V o g e l, dz. cyt., S. $176-216$.

${ }_{13}$ In Matth III, 16, 19; PL 26, 118; zob. W. Granat, dz. cyt., s. 352 . 
Jeszcze wyraźniej wypowiada się papież Leon Wielki w liście z 459 r. do biskupów Kampanii, w którym potępia niegodziwe nadużycie domagania się od penitentów spowiedzi publicznej z poszczególnych grzechów i sądzi, że taki zwyczaj jest sprzeczny z regułą apostolską oraz nakazuje bezwzględnie go usunąć. Zdaniem papieża, wystarczy odkryć plamy sumienia samym kapłanom przez spowiedź sekretną: ,sufficit enim illa confessio, quae primum Deo effertur, tum etiam sacerdoti, qui pro delictis paenitentium precator accedit" 14. Papież przytacza motywy przemawiające za usunięciem zwyczaju godnego potępienia. Otóż wielu wstrzymywało się od pokuty publicznej ze wstydu lub bojaźni przed karą, jaką grozi prawo. Wtedy bowiem możemy zachęcać ludzi do pokuty - uzasadnia papież - kiedy lud nie dowie się o sumieniu człowieka, który się spowiada. Zauważmy, że Leon Wielki uważa spowiedź za warunek konieczny dla odpuszczenia grzechów. Szafarzem odpuszczenia jest oczywiście biskup jako przełożony Kościoła lokalnego ${ }^{15}$. Od Leona Wielkiego - pisze ks. W. Granat - istniała w Kościele wyraźna świadomość, że wyznanie grzechów przed kapłanem i otrzymanie odeń pojednania jest konieczne $z$ woli Chrystusa, by otrzymać ich przebaczenie ${ }^{16}$. W Hiszpanii, w IV w., św. Pacjan, biskup Barcelony (zm. ok. r. 392), jako szafarzy sakramentu pokuty zna tylko ,sacerdotes Domini" 17.

Jeśli chodzi o praktyki pokuty w Galii rzymskiej, znamy je jedynie z dekretów synodalnych, z kazań św. Cezarego, arcybiskupa z Arles (zm. 543), i z listów papieży. Świadectwa są jednozgodne. Synod w Angers z $453 \mathrm{r}$. precyzuje, że osąd przewinień i naznaczenie pokuty jako też rozgrzeszenie penitentów należy do kompetencji biskupa: „Perspecta qualitate peccati secundum episcopi aestimationem erit venia largienda" ${ }^{18}$. Sw. Cezary, w jednym ze swych kazań przypomina, że do niego, jako do biskupa, powinni zwracać się grzesznicy, by uzyskać na drodze pokuty łaskę przebaczenia ${ }^{19}$.

Nie inaczej przedstawiały się $w$ tym czasie praktyki Kościoła w samym Rzymie. Według zachowanych świadectw, jeszcze w' IV i $\mathrm{V}$ w. nie znano tam innych spowiedników prócz swoich biskupów. W 416 r. papież Innocenty I, opisując zwyczaje pokutne swego Kościoła w liście do Decencjusza, biskupa w Gubbio, oświadcza, że` kompetencja osądzania ciężkości przewinień i jakość spowiedźi penitentów należy do biskupa: „De pondere aestimando delictorum sacerdotis est iudi-

14 Epist. 168; PL 54, 121; zob. W. Gran a t, dz. cyt., s. 352.

15 Epist. 58; PL 54, 1012; zob. W. Granat, dz. cyt., s. $322,352$.

16 Zob. W. Granat, dz. cyt., s. 322 .

17 Epist. ad Sympron. 1, 6; zob. E. V a c a n d a r d, art. cyt., DThC III, 841 ; W. Gran a t, dz. cyt., s. $300-301$.

18 Zob. M a n si, Conc., t. 7, k. 902; por. synod w Agde z r. 506, kan. 15, tamże, t. 8, k. 327 ; zob. E. V a c a nd a rd, art. cyt., DThC III, 841. 19 Zob. PL 39, 2218 - pomiędzy kazaniami św. Augustyna, 
care, ut attendat ad confessionem paenitentis" 20. Taką samą naukę, jak widzieliśmy powyżej, głosi papież Leon Wielki.

Jak z tego pobieżnego spojrzenia wynika, element wewnętrzny $\mathrm{i}$ indywidualny sakramentu pokuty, związany $\mathrm{z}$ wyznaniem grzechów szczegółowym i indywidualnym przed biskupem wzgl. kapłanem (prezbiterem), i element zewnętrzny, związany z praktyką pokuty publicznej, istnieją już w tym okresie $i$ - chociaż się nie spotykają jeszcze razem, lecz idą równolegle - w pewnym sensie się dopelniają. Wyznanie grzechów. indywidualne i szczegółowe nie wchodzi jeszcze wprawdzie w skład sakramentalnej pokuty, jak to usankcjonuje później sobór laterański IV, niemniej, jako czynność o charakterze informacyjnym, prywatnym, spełnia ona już wtedy ważną rolę w rozeznaniu stanu sumienia penitenta. Jest jednak rzecza historycznie prawie pewną, że w ciągu pierwszych pięciu wieków nie było w Kościele pokuty w sensie spowiedzi częstej i indywidualnej, jako odrębnej oficjalnej instytucji. Kościół trzymał się w tym czasie raczej zasady niepowtarzalności rozgrzeszenia. Zasada ta miała swoje uzasadnienie pastoralne sformulowane przez Tertuliana, który w dziełku De pudicitia uznaje, że Duch Pocieszyciel ma w Kościele władzę odpuszczania grzechów, ale niechce udzielać przebaczenia, gdyż byłoby to zachęta do dalszych grzechów ${ }^{21}$.

Taka zasada okazała się jednak w praktyce kłopotliwa i dla grzeszników i dla biskupów. Upokarzające praktyki pokuty publicznej, ich surowość i niemożliwość uzyskania powtórnego rozgrzeszenia, odstręczały wielu od wstępowania w stan pokutników (Ordo paenitentium). Stąd też biskupi sami, jako wyjście z tej kłopotliwej sytuacji i dla nich i dla wiernych, widzieli w tzw. paenitentia in extremis i zgadzaii się na udzielenie rozgrzeszenia na łożu śmierci, tj. przy końcu życia. Młodym zaś nie radzili za wcześnie wstępować w status paenitentium z obawy, by nie popadli ponownie w grzechy, dla których nie było już możliwości uzysikania przebaczenia przez praktykę trzeciej pokuty. Ten rygoryzm powstrzymywał tez wielu od wczesnego przyjęcia sakramentu chrztu, który również odkładano na ostatnie chwile życia, by w ten sposób, bez trudu, uzyskać przebaczenie grzechów 22.

W tym kontekście, gdzie panowała zasada niepowtarzalności rozgrzeszenia i rygoryzm praktyk pokutniczych, wyłaniał się jeszcze inny bardzo ważny problem, mianowicie: jakie stanowisko zając wobec tych chrześcijan, którzy powinni byli poddać się pokucie publicznej a odkładali ją na koniec życia i uczestniczyli w nabożeństwach liturgicznych i w samej Eucharystii, prżyjmując Ciało Pańskie?

20 Zob. PL 56, 517.

21 De pudicitia, XXI; PL 2, 1024 B; zob. W. Granat, dz. cyt., s. 271.

${ }_{22}$ Zob. W. Schenk, dz. cyt., s. 9 n; B. Pos chmann, dz. cyt., s. $95-97$; C. Voge 1 , dz. cyt., s. 205 ; J. R a mos-Regidor, art. cyt., s. $22-23$. 
Otóż wielu biskupów z tego okresu skarży się na stan opłakania godny, gdyż do stołu eucharystycznego przystępują ci, co są tego niegodni i nie odróżniają Stołu Pańskiego od stołu demonów ${ }^{23}$. W niektórych, bardzo jaskrawych wypadkach, biskupi interweniowali i ekskomunikowali najbardziej niegodnych, lecz nie wszystkich. Niektórym biskupi zabraniali przystępowania do Komunii św. na określony czas. Wielu jednak wiernych, poczuwając się w sumieniu niegodnymi przyjęcia Komunii św., opuszczało nabożeństwo eucharystyczne albo razem z katechumenami albo przed Modlitwą Pańską i błogosławieństwem biskupa. Widać z tego, że dotychczasowa praktyka pokuty publicznej i jednorazowej nie wytrzymywała próby czasu i wymagała zmiany ${ }^{24}$.

\section{PRZEJŚCIE DO PRAKTYKI INDYWIDUALNEJ I POWTARZALNEJ (VII w.)}

Ta zmiana przyszła z Irlandii i krajów celtyckich, czyli z okręgu kultury iroszkockiej, gdzie wypracowano w klasztorach nową praktykę pokuty dla mnichów i konwersów, po to właśnie, by mogli bez skrupułów przystępować do stołu eucharystycznego 25. Przeszczepiona i rozpowszechniona w VII i VIII w. na kontynencie Europy przez misjonarzy św. Kolumbana, ta nowa forma pokuty wprowadziła w dotychczasowe zwyczaje prawdziwy przewrót, gdyż usuwała najważniejszą przeszkodę: niepowtarzalność. Odtąd grzesznicy nie tylko mogli, ale byli zachęcani, by indywidualnie i często wyznawali w sekrecie swoje grzechy przed kapłanem. Ten, po udzieleniu zbawiennych rad i upomnień, nakładał penitentowi odpowiednią, w księgach specjalnych ustaloną pokute, nazwaną $z$ tej racji ,pokutą taryfową" (paenitentia taxata). Po wypełnieniu tej przepisanej pokuty penitent otrzymywał rozgrzeszenie i mógł ze spokojnym sumieniem przyjmować Eucharystię 26 .

Pierwsza wzmiankę o tego rodzaju praktykach pokuty spotykamy w dokumentach synodu w Toledo z 598 r. na którym biskupi z oburzeniem napiętnują ten nowy zwyczaj, nazywając go execrabilis praesumptio (can. 11). W Galii natomiast reforma karolińska (synody w Tours, Châlon, Reims i 829 w Paryżu) daremnie usiłowała wrócić do starej formy pokuty publicznej, która od r. 800 coraz bardziej zanikała i ustẹpowała regularnej spowiedzi 27. Wcześniej już jednak, gdyż na synodzie w Châlon-sur-Saône ok. r. 650, biskupi dają swoją apro-

23 Zob. Salwian z M arsylii, De gubern. Dei 8, 2; CSEL VIII, s. 196 ; por. C. Vog e 1, dz. cyt., s. 215 n.

24 Zob. Ks. W. S chenk, dz، cyt., s. 24 n; B. P os chm an n, dz. cyt., s. 103 n, 110; por. C. V o g e 1, dz. cyt., s. 215 n.

25 Zob. C. Vogel, dz. cyt., s. 214 n; B. Poschmann, dz. cyt., s. $110 \mathrm{n}$.

${ }_{26}$ Zob. Ks. W. S chenk, dz. cyt., s. 26; C. V og e 1, dz. cyt., s. 216 n.

27 Zob. C. Voge l, dz. cyt., s. 219 n; Ks. W. S c henk, dz. cyt., s. 26 n. 
batę i uznają użyteczność tej nowej praktyki: „De paenitentia vero peccatorum quae est medela animae, utilem omnibus hominibus esse censemus; et ut paenitentibus a sacerdotibus data confessione indicatur paenitentia, universitas sacerdotum noscitur consentire" 28.

Warto tu nadmienić, że w Kościołach celtyckich i anglo-saksońskich pokuta publiczna i jednorazowa nie była wcale znana. Grzesznik wyznawał indywidualnie ze wszystkimi szczegółami popełnione grzechy przed spowiednikiem, ten zaś pomagał $\mathrm{mu} w$ tym poznaniu samego siebie i oskarżeniu się przez stawiane mu pytania. W tej ankiecie służyły spowiednikowi, którym mógł być zwykły kapłan, specjalne instrukcje, tj. księgi penitencjalne ${ }^{29}$. O praktyce kilkakrotnego udzielania wiernym rozgrzeszenia indywidualnego na terenach Irlandii i Anglii przez kapłanów - kierowników duchownych - mowa jest w Paenitentiale (I, 13) Teodora, arcybiskupa Canterbury (zm. 690). W połowie VIII w. arcybiskup Egbert z Yorku (zm. 766) informuje, że praktyka wyznawania indywidualnie przed kapłanem swoich grzechów przed Bożym Narodzeniem, zarówno przez mnichów w klasztorach jak i przez wszystkich wiernych, jest na wyspach brytyjskich zwyczajem prawie powszechnie uznanym ${ }^{30}$. Podobną wzmiankę o corocznej praktyce spowiedzi wszystkich wiernych na początku W. Postu znajdujemy w wieku następnym u Teodulfa, biskupa z Orleanu (zm. 821) we Francji. Po wyznaniu grzechów przed kapłanem, według ustalonych przez specjalne instrukcje wzorów, kapłan odmawiał szereg modlitw i wyznaczał pokutę, którą penitent zobowiązany był wypełnić w okresie W. Postu. Rozgrzeszenie otrzymywał dopiero w W. Czwartek równocześnie $z$ tymi, którzy odbywali jeszcze publiçną pokutę za ciężkie publiczne przewinienia.

Tak więc w VII i VIII w. zwyczaj pokuty publicznej i jednorazowej ustępuje prawie zupełnie miejsca nowej praktyce pokuty sakramentalnej różniącej się od poprzedniej tym, że może być powtarzana ilekroć zajdzie tego potrzeba i bardziej złagodzonej, sprowadzonej do wyznania szczególowego grzechów i ich okoliczności w formie spowiedzi indywidualnej usznej przed kapłanem do tego uprawnionym oraz do wypełnienia nałożonej pokuty. Po wypełnieniu tejże pokuty następowało rozgrzeszenie, czyli odpuszczenie grzechów. Przejście to dokonało się bez wstrząsów i wielkich protestów a nawet przyjęte zostało z wielką uigą przez wiernych.

2 Synod w Chalon sur Saône ok. r. 639-654; zob. C. V og e 1, dz. cyt., S. 220 .

${ }_{29}$ Zob. B. Pos chmann, dz. cyt., s. 111 n; Ks. W. S chenk, dz. cyt., S. 12; J.-M. Szymusiak, Patrologia - Zagadnienia wybrane, Lublin 1971 ,s. 69-71; G. Le Bras, Pénitentiels, DThC XII, 1160-1179; C. V o'g e l, Bussbïcher, LThK II, 802-805.

${ }_{30}$ Dialogus eccles. institutionis, 16; zob. Ks. W. S chenk, dz, cyt., s. 26 . 
4. PRZEJŚCIE Z SYSTEMU POKUTY TZW. „TARYFOWWJ” DO SYSTEMIU OBECNEGO (IX - X w.)

Pomimo wprowadzonej zasady powtarzalności i złagodzenia form ekspiacji, pokutę przeszczepioną do Europy z krajów celtyckich cechował jeszcze rygoryzm, który aczkolwiek najlepsze miał cele, nie zachęcał wcale do częstej praktyki. Stąd, począwszy od końca VIII w., następuje dalsza ewolucja. Ekspiacja, czyli naprawienie zła, stanowiąca dotychczas element podstawowy jeśli nie najważniejszy sakramentu pokuty, ulega dalszemu złagodzeniu i schodzi na plan dalszy a punkt ciężkości przesuwa się coraz bardziej na szczegółowe wyznanie grzechów przed kapłanem. Wyznanie to zajmie w nowym systemie tak ważne miejsce, że stanie się w strukturze sakramentu pokuty aktem par excellence, elementem nieodzownym i obowiązkowym, a w mniemaniu wiernych sakrament pokuty utożsami się z pojęciem spowiedzi. Dodać tu również warto, że dzięki tej ewolucji zyskał też na wartości inny element, nieco zapomniany na skutek wprowadzenia pokuty taryfowej, a bardzo podkreślany w praktyce pokuty Kościoła pierwotnego - żal za grzechy, tj. wewnętrzne postawa skruchy.

Jako konsekwencja tego przestawienia akcentu z ekspiacji na wyznanie grzechów dokonała się ostatnia modyfikacja, mianowicie ta, że spowiednik będzie mógł rozgrzeszać penitenta bezpośrednio po wyznaniu mu grzechów, czyli bez czekania - jak to przewidywały księgi panitencjalne czy też kanony pokuty kościelnej — aż penitent wypełni nadaną mu pokutę. Od polowy $\mathrm{X}$ w. mamy świadectwa, że praktyka udzielania rozgrzeszenia bezpośrednio po spowiedzi była stosowana prawie $z$ reguły, tym bardziej odkąd ekspiację, czyli pokutę $w$ pierwotnym tego słowa znaczeniu, prawie zarzucono i zredukowano do symbolicznego aktu.

W IX w. pojawiają się na dworach możnych panów kapelani jako spowiednicy nadzwyczajni. Pojawiają się też teksty zawierające zalecenia o potrzebie systematycznego korzystania $z$ sakramentu rozgrzeszenia przynajmniej jeden raz albo trzy razy do roku, tj. w okresie wielkich świąt. Od IX w. zaczęto - najpierw tylko w wyjątkowych wypadkach, ,sivera interest causa”, a od roku 1000 ogólnie - udzielać rozgrzeszenia zaraz po spowiedzi św., odkładając wypełnienie pokuty na czas po rozgrzeszeniu ${ }^{31}$.

Od X w. spowiadano się zasadniczo przed każdorażowym przyjęciem Komunii św. Ogół wiernych na terenie Galii i Germanii przystępował wtedy tylko raz do roku, tj. w W. Czwartek, do Stołu Pańskiego, dlatego też źródła tego okresu mówią przeważnie tylko o spowiedzi wielkanocnej. Tam gdzie wierni kilka razy do roku przyjmowali Komunię św., spowiadano się przed każdą Komunią św. Tak

31 Zob. Ks. W. Schenk, dz. cyt., s. 27; B. Poschmann, dz. cyt., s. $122 \mathrm{n}$. 
pouczał św. Otton z Bambergu (zm. 1139) nowo nawróconych Pomorzan. Podobnie zarządził węgierski synod prowincjonalny w Granie (1114): ,Ut omnis populus in Pascha et in Pentecosten et Natali Domini paenitentiam agat et communicet, clerici vero in omnibus maioribus festis communicent" 32 .

\section{OD POCZĄTKOW SCHOLASTYKI DO POCZĄTKÓW REFORIMACJI (XII-XVI w.)}

Wprowadzona stopniowo jako zwyczaj praktyka dorocznej spowiedzi znalazła swoje sformułowanie prawne i stała się obowiązkowa na mocy dekretu soboru laterańskiego IV z r. 1215. Sobót ten ustalił, że „Każdy wierny, obojga płci, kiedy doszedł do lat rozeznania, powinien wiernie sam wyznać własnemu kapłanowi przynajmniej raz w roku wszystkie swe grzechy i starać się spełnić według sił swoich nałożoną pokutę" 33 .

Dekret ten jest o ogromnej doniosłości w historii rozwoju praktyki sakramentu pakuty, gdyż zamyka okres stopniowego przygotowania i ciagłego rozwoju praktyk tego sakramentu a otwiera okres ich stabilizacji i stawia zasadę obowiązkowej spowiedzi wielkanocnej. Wprawdzie dekret soborowy nie mówi o czasie, w którym należało „przynajmniej raz w roku” wyznać własnemu kapłanowi wszystkie swe grzechy. Zestawienie go jednak z równorzędnym nakazem przyjęcia - przynajmniej w okresie Paschy - sakramentu Eucharystii wskazuje dosyć wyraźnie, że chodzi tu o spowiedź wielkanocną stanowiąca warunek godnego przyjęcia Komunii św. wielkanocnej. Taka zresztą była ustalona tradycją praktyka spowiadania się na początku W. Postu, która doprowadziła do połączenia spowiedzi z Komunia św. Wielkanocną. Liczne synody usiłowały utrzymał tradycję spowiadania się w Środę Popielcową i wypełniania zadanej pokuty w całym okresie W. Postu, ale od XIII w. począwszy odkładano coraz częściej spowiedź na W. Tydzień, tak że duszpasterze z trudem zdołali wysłuchać wszystkich penitentów. Skutek tego połączenia spowiedzi i Komunii św. był taki, że obszerna w wiekach średnich liturgia spowiedzi uległa wielkim uproszczeniom.

Na szczególną uwagę zasługuje tu modyfikacja formuly rozgrzeszenia. Wymawiana dotad przez kapłana w formie deprekacyjnej modlitwy skierowanej do Boga o miłosierdzie nad grzesznikiem i o darowanie mu przewinień, przyjmuje ona w XIII w., na skutek akcentowania charakteru prawniczego sakramentu pokuty, formę orzekająca, analogiczną do sądowego wyroku, czyli orzeczenia trybunału $(, \ldots$ et ego te absolvo ..."), wyrażającą dobitniej władzę sądzenia i rozgrze-

32 Zob. M a n si, Conc., t. 21, 100; zob. Ks. W. S chenk, dz. cyt., s. 27.

33 Denz 812 (437); zob. Ks. W. Granat, dz. cyt., s. 344; Ks. W. S chen k, dz. cyt., s. 27 . 
szania powierzoną Kościołowi przez Chrystusa w sakramencie kapłan̆stwa ${ }^{34}$.

Tak więc w tym okresie, rozciągającym się od IV soboru laterańskiego, aż do wystąpienia Lutra i reformatorów, w praktyce sakramentu pokuty, ustalonej długą tradycją i jeszcze usankcjonowanej ostatnim dekretem soboru z r. 1215, nie nastąpiła żadna znaczniejsza ewolucja. Nastąpiła natomiast wyraźna zmiana optyki. Cała uwaga teologów i kanonistów tego okresu skupia się nie tyle na stronie pralstycznej i pastoralnej tego sakramentu, tj. na sposobach czy praktykach pokuty (actio paenitentialis) zmierzających przez ekspiację i wysiłek osobisty penitenta do rzeczywistej jej poprawy (metanoia) i nawrócenia, ile na stronie doktrynalnej albo - ściślej mówiąc - prawniczej. Skutek jest taki, że sakrament pokuty w swojej celebracji staje się coraz mniej czynnością w której uczestniczy aktywnie cała gmina wierzących a nabiera cech trybunalu, czyli instytucji w której kapłan udziela rozgrzeszenia po uprzednim wysłuchaniu samooskarżenia się samego penitenta przez spowiedź sekretną (in foro interno). Pojawiają się więc coraz liczniej opracowane systematycznie traktaty teologiczne o sakramencie pokuty, w których wiele miejsca poświęca się zagadnieniu potrzeby spowiedzi i jej przymiotów. W zwalczaniu zarzutów skierowanych przeciw obowiązkowi spowiedzi teologowie katoliccy starają się wyjaśnić, w jaki sposób nakaz spowiedzi zawarty został już w władzy kluczy, tj. rozgrzeszania udzielonej Kościołowi przez Chrystusa.

Najlepszą syntezę teologii scholastycznej z XIII w. odnośnie naszego zagadnienia dał św. Tomasz z Akwinu i jego szkoła. W świetle nauki św. Tomasza spowiedź jest conditio sine qua non dla úzyskania rozgrzeszenia, gdyż bez rozeznania sprawy penitenta i stanu jego sumienia kapłani, posiadający władzę kluczy, tj. rozsądzania i rozgrzeszania, nie moga wykonać sprawiedliwie swego urzędu ${ }^{35}$. $\mathrm{Z}$ warunkiem tym łączy się oczywiście przymiot integralności spowiedzi, czyli obowiązek wyznania spowiednikowi wszystkich grzechów ciężkich według ich liczby, rodzaju i okoliczności ${ }^{36}$.

Obowiązek ten powinien każdy chrześcijanin posiadający rozeznanie spełnić przynajmniej raz do roku ${ }^{37}$. Poza tym, zgodnie $z$ tym co już teologowie z drugiej połowy XIII w. wyraźnie stwierdzili, kapłani udzielający rozgrzeszenia winni posiadać oprócz święceń jeszcze specjalną do tego władzę zwaną jurysdykcją, odnoszącą się do określonego terytorium lub społeczności 38 .

34 Zob. K. R a hne r, Buss-Sakrament, w dz. zbior. Sacramentum mun-

$d i$, Herder Vg 1968, Bd I, $655-679 ; \mathrm{Ks}$. W. S chenk, dz. cyt., s. $32-33$.
Suppl. III, q. 6; Contra Gent. IV, 72; zob. W. Granat, dz. cyt., s. $196 \mathrm{n}$.

36 Suppl. III, q. 10, a. 4.

37 Suppl. III, q. 6, a. 3.

38 Suppl. III, q. 20 ; zob. W. Gr a n a t, dz. cyt., s. 197, 374. 
To, co warto szczególnie podkreślić w nauce św. Tomasza, to związek, jaki zachodzi między sakramentem pokuty, Eucharystii i kapłaństwa. Zdaniem Akwinaty, tylko kapłan jest szafarzem sakramentu pokuty i może być spowiednikiem, czyli może rozsądzać, rozgrzeszać i decydować, kogo dopuścić do przyjęcia Eucharystii, a kogo nie, bo tylko on posiada władzę konsekrowania, a co za tym idzie - władzę nad Ciałem Chrystusa w Eucharystii i obowiązek ustrzeżenia jej przed niegodnym przyjmowaniem ${ }^{39}$. W tym świetle wyznanie ustne grzechów ciężkich kapłanowi, połączone $\mathrm{z}$ pokutą wewnętrzną i zadośćuczynieniem, jest rzeczą nieodzowną i obowiązkową dla uzyskania rozgrzeszenia i stanowi warunek godnego przyjęcia Komunii św. W tym kierunku pójdzie też dalszy rozwój teologii sakramentu pokuty. Spowiedź z grzechów ciężkich przed kapłanem, w połączeniu z żalem za grzechy i otrzymanym rozgrzeszeniem, stanowić będzie zdaniem późniejszych teologów - warunek i najlepsze przygotowanie do godnego celebrowania Mszy św. i przyjęcia Eucharystii. Pragnienie natomiast częstego przyjmowania Eucharystii i troska o godne jej przyjęcie staną się punktem wyjścia dla praktyki częstej spowiedzi i to nawet $z$ grzechów lekkich ${ }^{40}$.

Jeśli chodzi o sam przebieg takiego szczegółowego wyznania grzechów przed kapłanem, był on bardzo długi i skomplikowany. Według źródeł z X i XI w., spowiednik stawiał penitentowi pytanie dotyczące pacierza i niektórych zasadniczych prawd wiary oraz czy przebacza swoim winowajcom. Po pozytywnej odpowiedzi nastąpowało przyjęcie wyznania grzechów. Wyznanie te odbywało się na podstawie różnych wzorów podanych w ksiegach penitencjalnych. Po wyznaniu grzechów penitent klękał i z rozłożonymi rękami prosił o przebaczenie, a spowiednik wyznaczał pokutę dostosowaną do ciężkości przewinień i warunków penitenta. Po spowiedzi odmawiano drugą połowę psalmów rozpoczętych na wstępie, dodawano siedem psalmów pokutnych przeplatanych wersetami i oracjami i Pater noster: Rozrzeszenia udzielano odmawiając kilka modlitw 41 .

\section{WYZNANIE GRZECHÓW W PRAKTYCE KOŚCIOEA OD SOBORU TRYDENCKIEGO DO NASZYCH DNI}

Ten dość skomplikowany obrzęd wyznania grzechów uległ dalszej ewolucji i uproszczeniu po soborze trydenckim. Sobór ten, jak wiemy, zajął się nie tylko doktrynalną stroną sakramentu pokuty i uzasadnił na XIV sesji z r. 1551 (rozdz. III, kan. 6-10) konieczność szczegóło-

39 IV Sent., dist. 17, q. 3, sol. 1; Suppl. III; q. 8, a. 1.

40 Zob. L. B r a e ckman s, Confession et communion au moyen-âge et au Concile de Trente, Gembloux 1971; A.-M. R o g u e t, Le sacerdoce du Christ, la rémission des péchés et la confession fréquente, LMD nr 56, 1958 , s. $50-70$.

${ }_{41}$ Zob. W. S ch en k, dz. cyt., s. 29-38. 
wego wyznania grzechów na spowiedzi przed kapłanem dla uzyskania rozgrzeszenia ${ }^{42}$, lecz - w wydanym w r. 1614 Rituale Romanum ustalił także strone obrzędową. Sobór precyzuje, że kapłanom, jako zastępcom Chrystusa pełniącym w Jego Kościele rolę przewodniczących, sędziów i lekarzy, należy wyznawać wszystkie grzechy śmiertelne, w jakie popadli chrześcijanie, choćby były one najbardziej ukryte, a. także ich okoliczności. Co do grzechów lekkich, chociaż ich wyznanie niè jest obowiązkowe, jest jednak bardzo pożyteczne dla wzrostu pobożności ${ }^{43}$. Wreszcie sobór stwierdza, że wyznanie grzechów, czyli spowiedź, istnieje w Kościele od samego początku, nie precyzuje jednak jaką miało formę i tym samym nie zamyka drogi dalszej ewolucji jej ceremoniału.

Jeśli chodzi o samą praktykę wyznania grzechów, to okres ten cechuje pewna jednolitość form, które przestrzegano aż do naszych czasów. Nie brak jednak w tym okresie, szczególnie w ostatnich dziesiątkach lat, prób adaptacji i dowartościowania tego sakramentu przez elementy o charakterze bardziej eklezjalnym i znalezienia nowych sposobów praktyki pokuty na drodze pewnego pluralizmu form ${ }^{44}$. Niektóre $z$ tych prób idą tak daleko, że chciałyby spowiedź idywidualna przed kapłanem zastąpić wyznaniem grzechów w formie spowiedzi powszechnej i zbiorowej.

Warto przypomnieć, że dnia 16 czerwca 1972 r. Święta Kongreg. Doktryny Wiary wydała za szczególną aprobatą Ojca św. dokument zawierający pastoralne wskazania i przepisy obowiązujące przy administrowanu sakramentu pokuty. Powołując się na naukę soboru trydenckiego, dokument ten stwierdza, że indywidualna spowiedź i towarzysząca jej indywidualna absolucja jest zwyczajną drogą dla wszystkich wiernych celem pojednania się z Bogiem i Kościołem, chyba że fizyczna lub moralna przeszkoda czyni indywidualne wyznanie grzechów niemożliwym. Mogą jednak zaistnieć wypadki, w których generalna absolucja może i powinna być udzielona bez uprzedniej indywidualnej spowiedzi, np. w obliczu niebezpieczeństwa utraty życia, a brak czasu nie pozwala na odbycie indywidualnej spowiedzi, albo gdy nie ma dostatecznej ilości kapłanów, by wysłuchać każdej indywidualnej spowiedzi $w$ określonym miejscu i czasie $i$ wobec tego wierni, szczególnie na terenach misyjnych, bez własnej winy byliby pozbawieni dobrodziejstw Komunii św. przez dłuższy okres. Do obowiązków ordynariuszy należy baczyć pilnie, by brak odpowiedniej liczby spowiedników nie został spowodowany niedbalstwem niektórych $\mathrm{z}$ nich $\mathrm{W}$ administrowaniu sakramentu pokuty. Wspólne nabożeństwa

42 Zob. C. Peter, Spowiedź integralna a sobór trydencki, Concilium $1-10,1971$, s. $35-41$.

43 Denz 899; por. encykl. Mystici Corporis 45; zob. Ks. W. S chenk, dz. cyt., s. 53 .

${ }_{44}$ Zob. F. Funke, art. cyt., s. $61-63$. 
pokutne żadną miarą nie mogą zastąpić sakramentalnej spowiedzi i absolucji. Kapłani winni pilnie zważać, by nie zniechęcać wiernych do częstych spowiedzi. Należy też stanowczo odrzucić opinię, że spowiedź indywidualna jest zarezerwowana dla grzechów ciężkich. ${ }^{45}$

\section{ZAKOŃCZENIE}

Spojrzenie na rozwój historyczny sakramentu pokuty wykazuje, że Kościól przywiązywał zawsze wielką wagę do wyznania grzechów i do przebaczenia udzielonego penitentowi przez Boga za pośrednictwem uprawnionych do tego ministrów. To wyznanie grzechów, zwane w terminologii pierwotnego Kościoła exomologesis, confessio lub publicatio sui, miało jednak w pierwszych trzech wiekach bardzo szerokie znaczenie i nie utożsamiało się bynajmniej z naszym pojęciem spowiedzi indywidualnej przed kapłanem. Powoływanie sie na te wyrażenia jako na argument istnienia od samych początków praktyki spowiedzi indywidualnej i sekretnej nie wytrzymuje krytyki, z drugiej jednak strony nie da się udowodnić, że takiej praktyki nie było. Jedno jest pewne, że to wyznanie grzechów umieszczone było w oprawę praktyk polzutnych, które miały wymiar społeczny i eklezjalny. Wniosek stąd praktyczny, że i dziś zagadnienia wyznania grzechów nie powinno się rozważać w oderwaniu od całego kontekstu praktyk pokutnych i od kontekstu eklezjalnego, tj. od wspólnoty religijnej, która cechuje pewna określona, świadoma i zdecydowana postawa wobec Boga i wobec grzechu - postawa wyznaczona przez sakrament chrztu, bierzmowania i Eucharystii, stanowiące punkt wyjścia i program życia chrześcijańskiego. Kościół bowiem to wspólnota, która wielbi Boga i wyznaje Jego świętość przez realizację ideału świętości w życiu osobistym swoich członków, wspólnota, która się zbawia i uświęca przez walkę z grzechem i pomaga jeszcze innym zwalczyć grzech i zmienić swoje postępowanie. W tej swojej misji wobec pokutującego grzesznika Kościół ma więc do spełnienia ważną funkcję pośrednika, wychowawcy i sędziego. Kościól nie tylko wstawia się za grzesznikiem do Boga o przebaczenie i podtrzymuje go w walce z grzechem, ale jako dobra matka współodpowiedzialna za jego zbawienie i za postawe swych dzieci - interweniuje w pewnym sensie w jego osobiste losy (przeznaczenie), udziela mu rad i upomnień, formuje jego sumienie, rozciąga kontrolę nad jego postępowaniem, osądza jego czyny, rozgrzesza i jedna z Bogiem tych, którzy po chrzcie zgrzeszyli, lecz przez pokute, czyli ekspiację, dają dostatecznå gwarancję poprawy (nawrócenia). Tę funkcję pośrednictwa, kontroli i osądzania oraz je-

45 Zob. dekret Kongreg. Doktr. Wiary: Sacramentum Paenitentiae normy duszpasterskie dotyczace udzielania generalnej absolucji sakramentalnej oraz komentarz i wypowiedź papieża Pawła VI na temat pewnych nierozważnych odchyleń od tych norm - Notitiae, nr 77, 1972, s. 305-326; Oręd. diec. chełmińskiej 1972, s. 287-290. 
dnania z Bogiem i Kościołem (rozgrzeszania) sprawowali w Kościele od samych początków jego istnienia jego zwierzchnicy, tj. biskupi $\mathrm{i}$ ich bezpośredni pomocnicy $\mathrm{w}$ kapłaństwie ministerialnym - prezbiterzy. Do XI w. praktyka wyprzedzała teologię tego sakramentu i szła w kierunku stałej adaptacji. Kierując się troską o człowieka i jego zbawienie, Kościół umiał dostosować się zawsze w szafarstwie łask Bożych (liturgii) do potrzeb i warunków człowieka. W wypadku grzechów ciężkich, wzgl. jawnych Kościół - jak to widzieliśmy w jego wielowiekowej praktyce sakramentu pokuty - zanim grzesznika rozgrzeszył upewnił się najpierw czy na to rozgrzeszenie zasługuje, tzn. czy jego nawrócenie pojęte jako powrót na drogę pierwotnej gorliwości wyznaczoną mu przez chrzest jest szczere i zdecydowane. Czynil to zaś nie w sposób anonimowy lub zbiorowy, w tym sensie, że grzesznik wyznawał swoje przewinienie razem $\mathrm{z}$ innymi $\mathrm{w}$ sposób ogólny i zatracał się niejako w tłumie i w zbiorowej odpowiedzialności przed Bogiem, ale przeciwnie - stawał bądź to przed całą społecznością (grzechy jawne), bądź to przed samym tylko zwierzchnikiem tej społeczności jako winowajca i grzesznik proszacy o przebaczenie i poprzez zwierzchnika gminy otrzymywał rozgrzeszenie i pojednanie.

Pomimo zmian i ewolucji form zewnętrznych istota sakramentu pokuty zachowała się po dziś dzień niezmieniona. Dziś stoi Kościól przed zadaniem nie łatwym, ale koniecznym, jeśli chodzi o sakrament pokuty - przed zadaniem przystosowania go do nowych warunków swojej misji. To przystosowanie nie może się mijać $z$ celem tego sakramentu i sprowadzać go na drogę czysto zewnętrznych rytualnych praktyk pokuty $\mathrm{z}$ pominięciem wyznania grzechów indywidualnego przed kapłanem i wewnętrznego zaangażowania w tym sakramencie odnowy wszystkich władz duchowych człowieka. Z drugiej strony nie może obstawać i zasadzać istoty tego sakramentu jedynie na aktach indywidualnych penitenta i spowiednika przypominających procedure trybunału. W parze $z$ dowartościowaniem teologii Kościoła musi iść dowartościowanie społecznego i eklezjalnego aspektu sakramentu pokuty w oparciu o społeczny charakter grzechu.

Pelplin

KS. BOLESEAW KOSECKI 